loom large. Possibly if the responsibility for economic development were taken from bureaucratic bodies and sharply dissociated from political circles, a more rapid advance could be achieved. It is the practical men, technologists and experts who are best equipped to regulate development of mineral wealth now lying dormant within the boundaries of the Empire. Indirectly such men are already furthering this object, both in an advisory capacity and by their contributions to magazines such as this. Several articles follow in illustration of the importance of mineral wealth. Mr. W. G. Boden writes of Canadian radium, showing how important it has become in the fight against cancer. Mr. L. Sanderson describes the rare metal niobium found in association with columbite and which is destined to play an important part in steel stabilisation and welded construction for service in the embrittling zone of temperatures. In addition there are descriptions of the mineral wealth of East Africa, Southern Rhodesia and the Gold Coast. Publicity of this character obviously furthers the case for utilization of British resources to meet British demands.

\section{Distribution of Insecticide by Shot-Gun}

Is a report from Science Service (Washington, D.C.) dated April 25 a patent is announced, and briefly described, embodying the application of insecticides by means of shells discharged from a kind of gun. The idea is an American invention, which claims that shot-gun shells can be loaded with compressed wads of insecticide instead of lead shot. When such a shell is fired, the force of the explosion ejects a wad like a bullet, and when it has travelled a certain distance, it breaks down into a cloud of ultra-fine dust. The distance at which the dissolution of the wad will occur depends upon its make-up-its compactness and moisture content. This distance, it is claimed, can be calculated so that the dust cloud can be discharged on a desired tree or erop. The advantages of the method, as claimed by the inventor, are safety of the operator from the effects of a toxic dust; elimination of cumbersome and explosive spray or dusting equipment; practically no labour ; and effective distribution of an insecticide in otherwise inaccessible places.

\section{Biochemical Research at the Franklin Institute}

We have received the third volume (1934-35) of "Reports of the Biochemical Research Foundation of the Franklin Institute". In a foreword, the director, Dr. Ellice McDonald, points out that this issue marks the withdrawal of the Cancer Research Laboratories of the Graduate School of Medicine from the University of Pennsylvania and their inception as the Biochemical Research Foundation of the Franklin Institute. The ostensible reason for this withdrawal is the refusal of the University to allow patenting of medical or biochemical discoveries for the continued furtherance of research activities, though not for personal profit. The Institute has decided that the past research done on the cancer problem should be made an avenue of approach to the more general area of other diseases. The objects of the new
Foundation are the study of the processes of disease from a chemical point of view, the study of new organic chemical compounds for their therapeutic value and the study of longevity and the diseases of age, with the hope of prolonging the span of life. The present volume contains reprints of some thirty papers published by the staff of the Institute and the Cancer Research Laboratories and their colleagues, dealing in general with various aspects of both normal and abnormal tissue metabolism.

\section{Business Mental Activity and Management}

Mr. W. R. DunLop, of 57 Gordon Square, London, W.C.1, who for a number of years has been interested in the study of business mental activity from the point of view of management and administration, and with particular reference to the logic and probability of decisions, desires to get into touch with a logician with a taste for probability arguments and a psychologist interested in the underlying psychological factors. It is desired, if possible, to arrange a private meeting for joint discussion at which an experienced business manager with introspective ability would also be present. The object would be to get a combined opinion on Mr. Dunlop's method and to make proposals for further studies and investigation. Mr. Dunlop would be greatly obliged if any reader would assist him in getting into touch with specialists willing and competent to collaborate in the direction indicated.

\section{Thomas Gray Memorial Trust}

THe Royal Society of Arts, through the Thomas Gray Memorial Trust, the objects of which are "the advancement of the Science of Navigation and the Scientific and Educational interests of the British Mercantile Marine", is offering the following prizes for competition in 1936: a prize of $£ 100$ to any person who may bring to their notice an invention, publication, diagram, etc., which is considered to be an advancement in the science or practice of navigation, proposed or invented by himself in the period January 1, 1931-December 31, 1936 ; a prize of $£ 100$ for an essay on the following subject: "What are your views as to the effectiveness or otherwise of Part II. of the Merchant Shipping (Safety and Load Line Conventions) Act, 1932, with special reference to vessels engaged in the carriage of oil and timber cargoes, and with particular regard to actual sea experience ?" Further information can be obtained from the Secretary, Royal Society of Arts, John Street, Adelphi, W.C.2.

\section{International Association for Quaternary Studies}

THE Association internationale pour l'Étude du Quaternaire européen, which met last at Leningrad in 1932, will hold its third session at Vienna on September 1-5. Prof. A. Penck is honorary president, Prof. G. Götzinger is president and Dr. O. Ampferer is president of the Organizing Committee. On this occasion, however, in accordance with a resolution passed at Leningrad, the scope of the Congress is to be the Quaternary in general and not the Quaternary of Europe only. Communications have already been 
promised on questions previously arranged for discussion in relation to the Quaternary of Austria and the Alpine glaciations covering stratigraphy, chronology, morphology, climate, prehistory and speleology. MM. Menghin, Kyrle, Beninger and Liebus will devote attention to the palæolithic period. Arrangements have been made for two excursions while the Congress is in session. Of these, one will visit the loess regions of the Danube Valley (Gottweig, Krems) and the other those in the neighbourhood of Vienna (Laaerbeg). At the close there will be a one-day excursion to the Drachenhöhle of Mixnits, while on September 7-8 an excursion will visit the loess of Weinviertel. Finally, a long excursion has been arranged for September 9-25, to visit the Austrian Alps and adjacent terrain. An illustrated guide-book is in course of preparation. Membership is a condition of attendance at the Congress, the annual subscription being 10 schillings (Austrian) or two dollars. In addition to the privilege of attendance at the Congress, members receive copies of reports which cover the progress of quaternary studies from 1908 until 1935. There are at present 180 members of the Congress drawn from twenty-five nations. Communications relating to the Congress or to membership should be addressed to Drs. Gotzinger and Ampferer, Geologische Bundesanstalt, Rasumofskygasse, Wien III, or to the General Secretary, Herr H. Gams, Botanische Institut, Innsbruck-Hötting.

\section{Announcements}

IT is announced that the Right Hon. Viscount Hailsham, the Lord Chancellor, has accepted the chairmanship of the British Empire Cancer Campaign.

At the meeting of the Paris Academy of Sciences on May 25, Paul Portier was elected a member of the Section of Medicine and Surgery, in succession to the late Charles Richet.

Dr. H. J. Plenderleirh, of the British Museum Research Laboratory, has been appointed professor of chemistry at the Royal Academy in succession to Dr. A. P. Laurie, whose term of office has expired. The professor of chemistry gives six lectures at the Royal Academy, in October and November. They are primarily intended for the Royal Academy students, but are open free to students of other art schools and Royal Academy exhibitors of the year who may wish to attend.

The Council of the Royal Meteorological Society has awarded the Howard Prize for 1936 to Cadet John Burton Davies, of H.M.S. Worcester. The subject of the competition was an essay on "The Causes of Fog over the Open Sea and in Coastal Waters".

WE much regret that the name of Prof. A. C. Seward, who is retiring from the chair of botany in the University of Cambridge which he has held since 1906, was inadvertently omitted from the list in NATURE of June 27, p. 1063 , of those on whom the honour of knighthood has been conferred.
ON the occasion of the Congress of Psychiatry held at Rome on April 3, a bust of the neurologist and psychologist, Prof. Sancte de Santis, was unveiled by Prof. Ponzo.

Dr. Marshall C. Balfour, representative in Greece of the International Health Board of the Rockefeller Foundation, has been awarded the silver medal for distinguished services by the Greek Academy of Sciences, Arts and Letters in recognition of his researches on malaria control in the Peloponnese and Macedonia.

THE eleventh International Congress of Psychology will be held at Madrid on September 6-12 under the patronage of the Spanish Republic and the presidency of Prof. E. Mira of Barcelona. The official languages will be Spanish, English, French, German and Italian. Further information can be obtained from the general secretary, Dr. José German, Instituto Nacional de Psicotecnica, Alberto Aguilera 25, Madrid.

Applications are invited for the following appointments, on or before the dates mentioned :

A lecturer in anatomy in the University of Birm. ingham-The Secretary (July 7).

A scientific officer (physics or engineering) in a Government establishment in the south of England -The Secretary, Royal Engineer Board, Regent's Park Barracks, Albany Street, London, N.W.1 (July 7).

A technical assistant (male) in the Air Defence Experimental Establishment, Biggin Hill, KentThe Superintendent (July 7).

A lecturer in production engineering in the County Technical College, Wednesbury-The Director of Education, County Education Offices, Stafford (July $9)$.

An assistant lecturer in civil engineering in the City and Guilds College, Imperial College of Science and Technology, Prince Consort Road, South Kensington, S.W.7-The Secretary (July 10).

Chemists (male) at the War Department Chemist, Woolwich Arsenal-The Under-Secretary of State (C.5), The War Office, London, S.W.1 (July 10).

A lecturer in mechanical engineering in the Heanor Mining and Technical School-The Director of Education, County Education Office, St. Mary's Gate, Derby (July 11).

Two assistants (Grade I), one assistant (Grade II) and two junior assistants in the Directorate of Explosives Research; and an assistant (Grade II) in the Directorate of Metallurgical Research in the Research Department, Royal Arsenal, WoolwichThe Chief Superintendent (July 11).

A lecturer in mathematics in the University of Aberdeen-The Secretary (July 17).

A lecturer in physiology in the University of Birmingham-The Secretary (July 17).

A demonstrator in human physiology in the University of Manchester-The Registrar (July 18).

A professor of social anthropology in the University of Oxford-The Registrar. 